Yun et al. Journal of Open Innovation: Technology, Market, and Complexity (2015) 1:16

DOI 10.1186/s40852-015-0020-x
( ) Journal of Open Innovation: Technology, Market, and Complexity a SpringerOpen Journal

\title{
RESEARCH
}

Open Access

\section{Open innovation of knowledge cities}

\author{
JinHyo Joseph Yun ${ }^{1}$, EuiSeob Jeong ${ }^{2^{*}}$ and JeongHo Yang ${ }^{1}$
}

\footnotetext{
* Correspondence: esjng@kisti.re.kr

${ }^{2}$ Korea Institute of Science and Technology Information (KISTI), Hoegi-ro, 66 Dongdemun-gu, Seoul 130-741, South Korea

Full list of author information is available at the end of the article
}

\begin{abstract}
Purpose: This research seeks to answer the basic question, "As a city evolves from an industrial city to a knowledge one, are its open innovation activities vitalized?"

Design/methodology/approach: In this research, we compare the total number of patent applications, the number of joint applicants of each patent, and the ratio of patents jointly applied, in four Korean cities-Daegu, Kwangju, Cheonann total, top $10 \%$ patent applicants group among total patent applicants, and the lower $70 \%$ patent applicant group among total patent applicants. The research included 144,625 patents submitted to the Korea Patent Office from 1981 to 2010.

Findings: As knowledge-based urbanization proceeds, the size of a knowledge city increases. The lowest $70 \%$ of patent applicants (rather than the top $10 \%$ ) apply for more patents, and the breadth and depth of open innovation rises.

Research limitations/implications (if applicable): This research is limited to mutual patent applications as a target of open innovation. In the future, additional research will need to be conducted on various open innovation channels such as patent citation, intellectual property right transfer, licensing, and M\&A.

Practical implications (if applicable): To maximize the beneficial characteristics of a knowledge city in a large city, the improvement of open innovation across the city is essential.

Social implications (if applicable): If strengthening open innovation by SMEs or start-ups is set as a corporate strategy or a government policy, it will be a source of development of knowledge-based urbanization and continued economic development of a knowledge city, as well as of the total knowledge assets.
\end{abstract}

Keywords: Knowledge City, Open innovation, Power law, Long tail

\section{Introduction}

The creative, cultural knowledge city has recently received considerable attention, not only from researchers, but also from businesses and the public at large (Musterd, 2004). The generation of economic growth by knowledge spillover has been increasing, and is particularly effective in cities where communication between people is more extensive (Glaeser et al. 1991). Therefore, as a city changes from an industrial to a knowledge-based one, it is expected that knowledge will spread even more. Although the recently emerging idea of a "knowledge city" is complex and difficult to define, several perspectives have already been used for its definition. Some of these perspectives include economic, value-based, sociological, quantitative, structural, and historical (Dvir, 2006). 
Taking this into consideration, in this research, we compared and analyzed the concrete process of knowledge-based urbanization of four (two large, one medium, one small) Korean cities over 30 years by understanding a 'knowledge city' as a quantitative concept. We analyzed the procedural change of a traditional Korean industrial city in 1980 to a knowledge city in 2010 through industrialization. In a previous study, Florida determined why cities without gays and rock bands were losing the economic development race (Florida, 2002). This was done by measuring the creativity of a city through the use of its gay or rock band figures. In addition, he concretely developed the Bohemian Index or Gay Index, which measures the concentration of artists, musicians, and similar types of creative people working in a fixed region, and thereby indicated the creativity of a city (Florida, 2005, p. 34).

Similarly, this research was intended to analyze the difference between the status and the level of knowledge-based urbanization between cities through the use of patent application data. The data used for this analysis was from patent applications submitted to the Korean Intellectual Property Office from 1 January 1981 to 31 December 2010, in four Korean cities (Daegu, Kwangju, Cheonan, and Gumi). To compare and analyze the level of knowledge-based urbanization, we first compared and analyzed changes over time in the total number of patent applications. Second, we performed a time sequential comparison and an analysis of Intensity of Open Innovation (IOI), which indicated the open innovation status based on the number of joint applicants of each patent. Third, we performed a time-sequential comparative analysis of Ratio of Open Innovation (ROI), which provided the ratio of patents jointly applied by two or more people, against all patents. In addition, the patent applicants of each city were divided into two groups. Subsequently, the time sequential difference between cities was analyzed in terms of the total amount of patents, ROI, and IOI (Yun, et al., 2014).

The goal of this research was, through comparative analysis, to answer the basic question, "As a city evolves from an industrial city to a knowledge one, are its open innovation activities vitalized?" To achieve this goal, objectives in the form of three research questions were formulated. First, as a city changes from an industrial city to a knowledge city, does the breadth of open innovation increase? That is, among the patent applications of a city, is the ratio of joint patent applications against single patent applications increasing? Second, as a city changes from an industrial city to a knowledge city, does the depth of open innovation increase? Is the number of patent applicants on each patent in a city increasing? Third, as a city changes from an industrial city to a knowledge city, do the long tail phenomenon, and the power law phenomenon, strengthen open innovation of any city? If possible, we want to answer an additional question, is the long tail phenomenon, rather than the power law phenomenon, strengthened for open innovation, or not.

In addition to these questions, this research resolved the following concrete research issues as well. First, does the ratio of the lowest $70 \%$ group, rather than the top $10 \%$ group, increase among the patent applicants of a city? Second, does the lowest $70 \%$ group increase more than the top $10 \%$ group in terms of patent application activities with open innovation, which represents the ROI and IOI of a city?

To answer these questions, at the first part of this research, literature review was done. This allowed us to summarize the relation between the knowledge-based urbanization level of a city and its open innovation research, as well as to analyze 
previous determinations of the level of knowledge-urbanization or creative urbanization. We were also able to summarize literature reviews on the power law and long tail to identify the characteristics of the upper and lower groups of patent applicants of a city. From these, the research hypothesis of this research was set.

Second, using the comparative analysis of patent application status, ROI, and IOI, in this research, we compared and analyzed the open patent-application-change procedure of four cities such as Daegu, kawanju, Gumi, and Cheonan in accordance with knowledge-based urbanization from 1981 to 2010. Then, we compared the analysis results of the four cities, and the patent ratio change of each of several industries. Subsequently, we interpreted the change of the meaning of a city's open innovation patent. Third, it draws the power law and long tail phenomenon of each city through the top $10 \%$ group and the lowest $70 \%$ group of the patent applicants of each city. Then, it analyzes the change of the ratio and the open innovation patent application of each city cities. Fourth, herein we discuss the theoretical and practical issues of the relation between a knowledge city and open innovation, including the relation between the power law and long tail. Lastly, we summarize the results of this research, and propose issues for future research.

\section{Literature review and research design}

\section{Review of preceding research and setting of hypothesis}

In this research, we first examined preceding research related to knowledge spillover and to open innovation of a knowledge city. From this, we created an index for comparison between the cities that have changed, or are changing, from industrial to knowledge cities. As a knowledge economy develops, asymmetrical knowledge in "regional knowledge capabilities" between regional innovation systems, or between clusters such as regions or cities, motivates open innovation (Cooke, 2005). That is, the development of a knowledge city leads to activation of open innovation in this city (Carrillo, 2015; Hand and Cho, 2015; Inkinen, 2015; Kodama and Shibata 2015; Patra and Krishna, 2015). Fortunately, patent citations could be used as a direct indication of knowledge flows (Breschi, et al., 2005). Similarly, we can compare the geographic location of patent citations with that of the cited patents, as evidence of the extent to which knowledge spillovers are geographically localized (Jaffe et al. 1993). Meanwhile, the breadth of open innovation, that is, the ratio of open innovation based on collaborative patents (ROI), and the depth of open innovation, the intensity of open innovation based on collaborative patents (IOI), can be directly determined using collaborative patent applications (Yun, et al., 2014). The efficiency of transmitting knowledge for economic applications is seen as a crucial factor in explaining the economic growth of urban cities (Raspe and Van Oort, 2006). Four modes of knowledge creation-socialization, externalization, combination, and internalization - have open innovation characteristics (Nonaka, 1994). Cluster formation is a process that relies on the coevolution of technology, business models, and local supporting institutions. Moreover, a prominent feature of cluster formation is the importance of entrepreneurship (Feldman and Braunerhjelm, 2006). There is a strong correlation between entrepreneurship and open innovation. Moreover, entrepreneurship has an additional moderating effect that positively affects the benefits of open innovation on the performance of firms (Yun, et al., 2013). According to the results from a simulation and a national analysis, a policy promoting open innovation within a 
system of national innovation, even in a nation at an early stage of development, has a distinctly positive impact on the rapid growth of the nation (Yun, et al., 2015). In addition, intra-industry knowledge spillovers are less important for growth than those across industries, particularly in the case of fairly mature cities (Glaeser, et al., 1991). This means that maturation of large cities to form knowledge cities seems to occur by knowledge transmission that occurs via adoption of open innovation by an expanding list of sectors. From all this, the following hypotheses were formed.

Hypothesis 1: Open innovation increases as knowledge-based urbanization proceeds. Hypothesis 2: The bigger a city is, the larger its open innovation is.

The second part of this work involved looking at preceding research to analyze the trends of centralization and diversification related to knowledgebased urbanization, that is, existing research on the power law and long tail concept. According to a data analysis described in the 1996 Forbes 400 list of the richest people in the US, wealth is distributed according to a power law (Levy and Solomon, 1997). The probability density function describing the distribution of incomes is of the form:

$$
\mathrm{P}(\mathrm{I})=C I^{-(1+\alpha)}
$$

where $\mathrm{I}$ is the income, the coefficient $\alpha$ is known as the Pareto exponent, and $\mathrm{C}$ is a normalization constant (Say, 1844). Later, it was found that wealth is also distributed following a power law (Atkinson and Harrison, 1978). According to other research that analyzed data on wealth and income distributions in the United Kingdom, as well as income distributions in individual US states, a great majority of the population is described by an exponential distribution, whereas the high-end tail follows a power law (Dragulescu and Yakovenko, 2001). Mathematically, a quantity $\mathrm{x}$ obeys a power law if it is drawn from a probability distribution:

$$
p(x) \propto x^{-\alpha}
$$

where $\alpha$ is a constant parameter of the distribution known as the exponent or scaling parameter (Clauset et al., 2009). According to Clauset et al. (2009), in reality, few empirical phenomena obey power laws for all values of $\mathrm{x}$. In addition, more often, the power law only applies for values greater than some minimum $\mathrm{x}$. Because the increase in knowledge in a knowledge-based economy indicates increased wealth, it can be presumed that operation of the power law phenomenon in the accumulation of wealth in a region or city, is based on operation of the power law phenomenon in the accumulation of knowledge (Cooke and Leydesdorff, 2006; Foray and Lundvall, 1998). Actually, the power law phenomenon is exhibited in activities related to the production and distribution of knowledge, such as the number of citations or the number of academic papers (Clauset et al. 2009; Redner, 1998). Several markets have historically been dominated by a small number of best-selling products, which is embodied in the Pareto Principle as the $80 / 20$ rule. This describes a common sales pattern. Thus, as knowledge-based urbanization proceeds, it is expected that more of the patent applications of the top $10 \%$ of patent applicants among total patent applicants of each city 
will tend to be of the open-innovation type. From this, the following hypothesis is made.

Hypothesis 3: As knowledge-based urbanization proceeds, open innovation increases among the top $10 \%$ of patent applicants of a city.

However, information technology generally, and Internet markets in particular, have the potential to substantially increase the collective share of niche products, thereby creating a longer tail in the distribution of sales (Brynjolfsson, et al., 2011). According to these workers, internet channel retailers exhibit a significantly less concentrated sales distribution compared with traditional channels. In addition, peer-based recommendations associated with electronic commerce lead to a redistribution of demand from popular products (blockbusters) to less popular (niche) products. As such, electronic markets will, therefore, be characterized by a "long tail" of demand and revenue (Oestreicher-Singer and Sundararajan, 2010). Moreover, the impact of weak ties and improved contact management creates a vast potential for online networking, which is the long tail of social networking (Enders, et al., 2008). Even if a research result is that there is hardly a long tail effect, if a recommendation network or a social network is included, rather than just online sales, long tails will appear in accordance with the results presented in a variety of other research (Elberse, 2008; Enders, et al., 2008; Oestreicher-Singer and Sundararajan, 2010). Multidisciplinary collaboration increases the variance of the outcome, the so-called diversity or long tail of innovation. As such, both failures and breakthroughs become more probable. This is called the effect of multidisciplinary collaboration (Fleming, 2012). As for recommendations or social networks, the collaboration of knowledge, such as occurs during patent creation, appears as a long tail. In particular, collaboration across diverse fields leads to creativity (Yun and Cho, 2014). Thus, the following hypothesis can be posited.

Hypothesis 4: As knowledge-based urbanization proceeds, the open innovation of the lowest $70 \%$ of patent applicants of a city will increase.

\section{Research framework}

In this work, the research framework (design) is configured as shown in Fig. 1 and Table 1. As shown, the size of the cities is indicated on the vertical axis, while the power law phenomenon (top $10 \%$ ) and the long tail phenomenon (lowest $70 \%$ ) among all patent applicants are placed on the horizontal axis.

It was assumed that changes in knowledge-based urbanization in an industrial city occurs on a ten-year basis (i.e., it should be observable over a period of ten years). From this, the ten-year period in the 1980s (1980-1989) was compared with that in the 2000s (2000-2009). Rather than focusing on the information in consecutive years, in this work, we compared the status and depth of open innovation for 10 years. This was done to eliminate statistical analysis errors that have an impact on the statistical outliers created by special conditions, such as Korea's economic crisis in the 1990s (Siervogel et al., 1991). In addition, the change in industrial structure was subjected to a technical statistical analysis to determine the change per decade in knowledge-based 


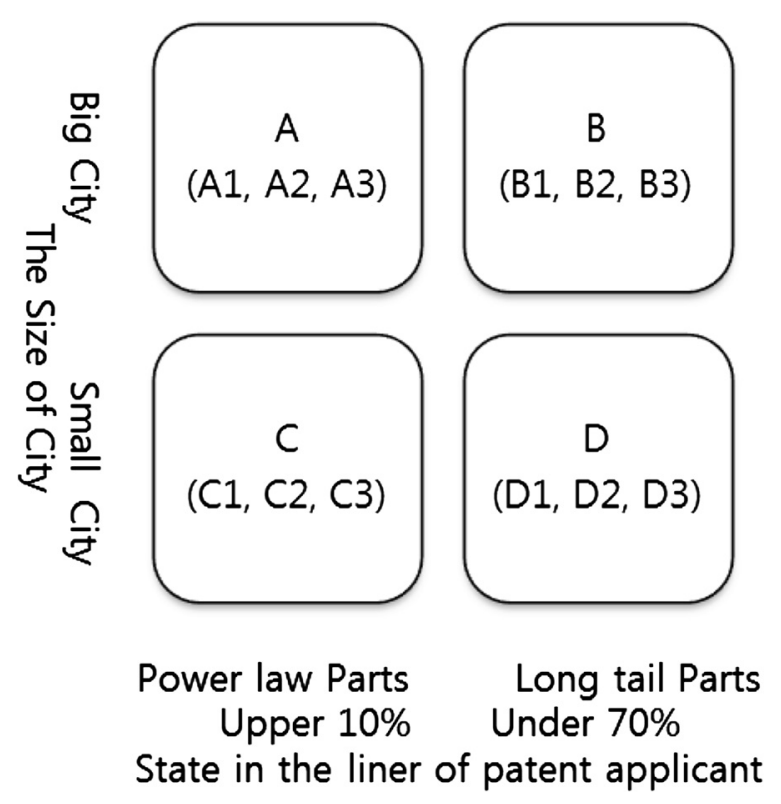

Fig. 1 Research design

urbanization, before analyzing the research issues. Moreover, the status of open innovation was estimated with breadth and depth in accordance with previous research (Laursen and Salter, 2006). Breadth was indicated by the ratio of open innovation (ROI), which is the ratio of patent applications with two or more applicants among all patent application cases. Depth was indicated by the intensity of open innovation (IOI), which is the average number of patent applicants on each patent (Yun, et al., 2014). The criterion for determining the size of a city was population. The big cities in this study have a million or more population (Peterson, 1981). In accordance with the Pareto Law, the top $10 \%$ clearly appeared as the distribution connected with the power-law-measurement section, and the lowest $70 \%$ generally appeared connected with the long-tail phenomenon.

\section{Technical statistical analysis}

This research targeted 144,625 patent applications submitted to the Korean Intellectual Property Office by applicants in Daegu, Kwangju, Gumi, and Cheonan during 30 years (1981 to 2010), as described in Table 2. As in Appendix 1, the table shows patents in two big cities with a population of a million or more, and in two small cities with a population of less than a million, in Korea. As of 2010, Daegu has the largest population, followed by Kwangju, Gumi, and Cheonan.

In terms of Gross Regional Domestic Product (GRDP), Daegu has the largest GRDP followed by Kwangju, Gumi, and Cheonan. From the 1980s to the 1990s, the number of patent applications increased. For example, patent applications in Gumi grew 12.9 times, and those in Kwangju rose 6.4 times. Patents applied in Cheonan increased 5.9 times, and those in Daegu grew 2.2 times. However, during the 1990s and 2000s, patent applications in Cheonan increased 4.1 times, and those in Kwangju grew 1.9 times. Patent applications in Daegu increased 1.7 times, 
Table 1 Research structure and hypotheses

\begin{tabular}{|c|c|c|c|}
\hline Hypothesis & Hypothesis content & Hypothesis & Related literature and theoretical roots \\
\hline \multirow[t]{4}{*}{ Hypothesis 1} & $A 1+B 1<A 3+B 3$ & H 1-1 Daegu 80 s $<00$ s & \multirow{4}{*}{$\begin{array}{l}\text { (Cooke, 2005); (Nonaka, 1994); } \\
\text { (Feldman and Braunerhjelm, 2006); } \\
\text { (Yun, et al., 2015); (Breschi, et al., 2005) } \\
\text { (Yun, et al., 2014) }\end{array}$} \\
\hline & $\begin{array}{l}\mathrm{A} 1+\mathrm{B} 1=\text { Daegu } 80 \mathrm{~s} \\
\text { or Kwangju 80s }\end{array}$ & H 1-2 Kwangju 80s <00s & \\
\hline & \multirow{2}{*}{$\begin{array}{l}\mathrm{A} 3+\mathrm{B} 3=\text { Daegu 00s } \\
\text { or Kwangju 00s }\end{array}$} & H 1-3 Gumi 80 s < 00s & \\
\hline & & H 1-4 Cheonan 80s <00s & \\
\hline \multirow[t]{4}{*}{ Hypothesis 2} & $A+B>C+D$ & H 2-1 Daegu 00s > Gumi 00s & \multirow{4}{*}{$\begin{array}{l}\text { (Jaffe, et al., 1992); (Raspe and } \\
\text { Van Oort, 2006); (Yun, et al., 2013); } \\
\text { (Yun, et al., 2014) }\end{array}$} \\
\hline & $\begin{array}{l}A+B=\text { Daegu } \\
\text { or Kwangju }\end{array}$ & H 2-2 Daegu 00s > Cheonan 00s & \\
\hline & \multirow{2}{*}{$\begin{array}{l}\mathrm{C}+\mathrm{D}=\text { Gumi } \\
\text { or Cheonan }\end{array}$} & H 2-3 Kwangju 00s > Gumi 00s & \\
\hline & & H 2-4 Kwangju 00s > Cheonan 00s & \\
\hline \multirow[t]{6}{*}{ Hypothesis 3} & $\mathrm{~A} 1<\mathrm{A} 3$ & H3-1 Daegu $10 \% 80$ s < 00s & \multirow{6}{*}{$\begin{array}{l}\text { (Levy and Solomon, 1997); (Atkinson } \\
\text { and Harrison, 1978); (Cooke and } \\
\text { Leydesdorff, 2006; Foray and } \\
\text { Lundvall, 1998); (Clauset, et al., 2009; } \\
\text { Redner, 1998); (Yun, et al., 2014) }\end{array}$} \\
\hline & $\mathrm{C} 1<\mathrm{C} 3$ & H3-2 Kwangju $10 \%$ 80s<00s & \\
\hline & $\begin{array}{l}\mathrm{A} 1=\text { Daegu } 10 \% 80 \mathrm{~s} \\
\text { or Kwangju } 10 \% 80 \mathrm{~s}\end{array}$ & H3-3 Gumi $10 \% 80$ s < 00s & \\
\hline & $\begin{array}{l}\mathrm{A} 3=\text { Daegu } 10 \% \text { 00s } \\
\text { or Kwangju } 10 \% \text { 00s }\end{array}$ & \multirow[t]{3}{*}{ H3-4 Cheonan $10 \%$ 80s < 00s } & \\
\hline & $\begin{array}{l}\mathrm{C} 1=\text { Gumi } 10 \% 80 \mathrm{~s} \\
\text { or Cheonan } 10 \% 80 \mathrm{~s}\end{array}$ & & \\
\hline & $\begin{array}{l}\mathrm{C} 3=\text { Gumi } 10 \% \text { 00s } \\
\text { or Cheonan } 10 \% \text { 00s }\end{array}$ & & \\
\hline \multirow[t]{6}{*}{ Hypothesis 4} & $\mathrm{~B} 1<\mathrm{B} 3$ & H4-1 Daegu $70 \%$ 80s < 00s & \multirow{3}{*}{$\begin{array}{l}\text { (Brynjolfsson et al. 2011); (Simester, } \\
\text { 2011); (Oestreicher-Singer \& } \\
\text { Sundararajan, 2010); (Enders et al. } \\
\text { 2008) }\end{array}$} \\
\hline & $\mathrm{D} 1<\mathrm{D} 3$ & H4-2 Kwangju $70 \% 80$ s < 00s & \\
\hline & $\begin{array}{l}\text { B1 }=\text { Daegu } 70 \% 80 \mathrm{~s} \\
\text { or Kwangju } 70 \% 80 \mathrm{~s}\end{array}$ & H4-3 Gumi $70 \% 80$ s < 00s & \\
\hline & $\begin{array}{l}\text { B3 }=\text { Daegu } 70 \% \text { 00s } \\
\text { or Kwangju } 70 \% 00 \text { s }\end{array}$ & \multirow[t]{3}{*}{ H4-4 Cheonan $70 \%$ 80s < 00s } & \multirow{3}{*}{$\begin{array}{l}\text { (Elberse, 2008; Enders et al. 2008; } \\
\text { Oestreicher-Singer \& Sundararajan, } \\
\text { 2010); Yun et al. 2014) }\end{array}$} \\
\hline & $\begin{array}{l}\text { D1 = Gumi } 70 \% 80 \mathrm{~s} \\
\text { or Cheonan } 70 \% 80 \mathrm{~s}\end{array}$ & & \\
\hline & $\begin{array}{l}\text { D3 = Gumi } 70 \% \text { 00s } \\
\text { or Cheonan } 70 \% \text { 00s }\end{array}$ & & \\
\hline
\end{tabular}

and those in Gumi increased 1.2 times. Overall, the rate of patent application in Gumi significantly decreased, while that in Cheonan rose sharply. It can be assumed that the relocation of a considerable portion of Samsung and LG-both of which were originally located in Gumi-to Cheonan and Paju, respectively, caused these changes. To sum up, the four cities showed very different results in terms of increase in patent applications.

However, as in Appendix 2: Table 5, according to the result from analysis of patentbased industrial change in the four cities over ten year intervals, the characteristics of

Table 2 Patents applications during 30 years in four Korean cities

\begin{tabular}{llllll}
\hline Year & Subtotal & Daegu & Kwangju & Gumi & Cheonan \\
\hline $1981-1990$ & 12,724 & 9603 & 1663 & 795 & 686 \\
$1991-2000$ & 46,369 & 21,446 & 10,694 & 10,240 & 4063 \\
$2001-2010$ & 85,532 & 36,096 & 20,455 & 12,486 & 16,834 \\
Total & 144,625 & 67,145 & 32,812 & 23,521 & 21,583 \\
\hline
\end{tabular}

Source: KISTI database (http://patent.ndsI.kr) 
knowledge-based urbanization can be determined (Dalziel, 2007; Yigitcanlar, 2008). The approach here corresponded to the technology classification of the World Intellectual Property Organization (WIPO) and the industry classification of McKinsey. In our research, these characteristics included such as the constant increase in the ratio of high innovation industry and domestic technology industry in the four cities during the process of change over 30 years (Fig. 2). That is, in terms of the knowledge-based urbanization trend, the four cities showed a similar trend even though there were slight differences in timing and specific results.

In this research, we examined change in the status of open innovation in the four cities as they went through the process of knowledge-based urbanization. This work was based on the technical statistical analysis of patent data (Hypothesis 1); that is, the difference of the change of open innovation characteristics of big and small cities (Hypothesis 2), the change of open innovation characteristics of the top $10 \%$ of patent applicants (Hypothesis 3), and the change of open innovation characteristics of the lowest $70 \%$ of patent applicants (Hypothesis 4).

\section{Analysis of change in the level of open innovation according to the development of a knowledge city}

Change in the depth and breadth of open innovation in the four cities

Three of the four cities (Cheonan was the exception) increased the depth and breadth of open innovation in the 2000s, compared with those in the 1980s (Fig. 3). According to Appendix 2: Table 5, among the top 20 patent applicants over 30 years, hardly any patent applications were submitted in Cheonan in the 1980s. Even in the 1990s, the number of patent application cases was very small compared with the number in the 2000s. In addition, Cheonan came to surround the cities of Asan and Tangjeong, which are company cities led by a single large company, Samsung Display, since the 2000s. As a result, the city rapidly proceeded with its knowledge-based urbanization (Yun, et al. 2010).

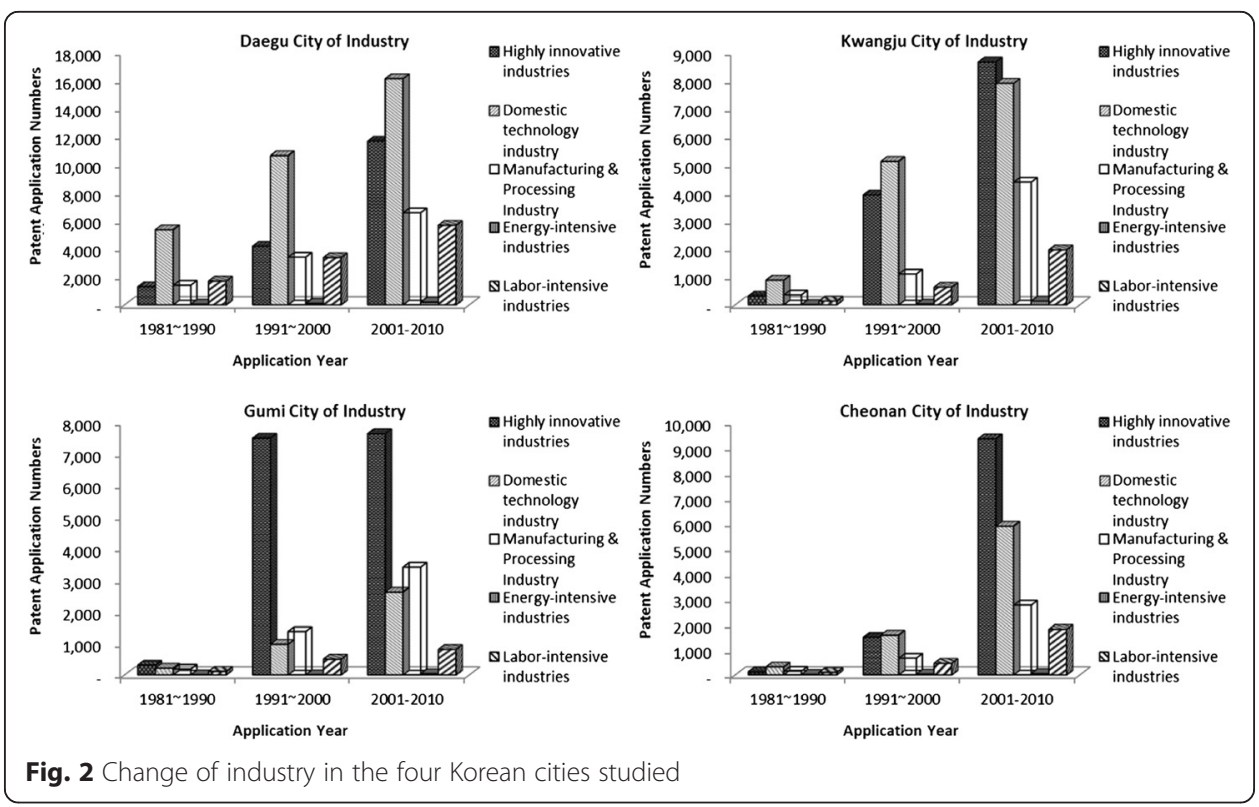




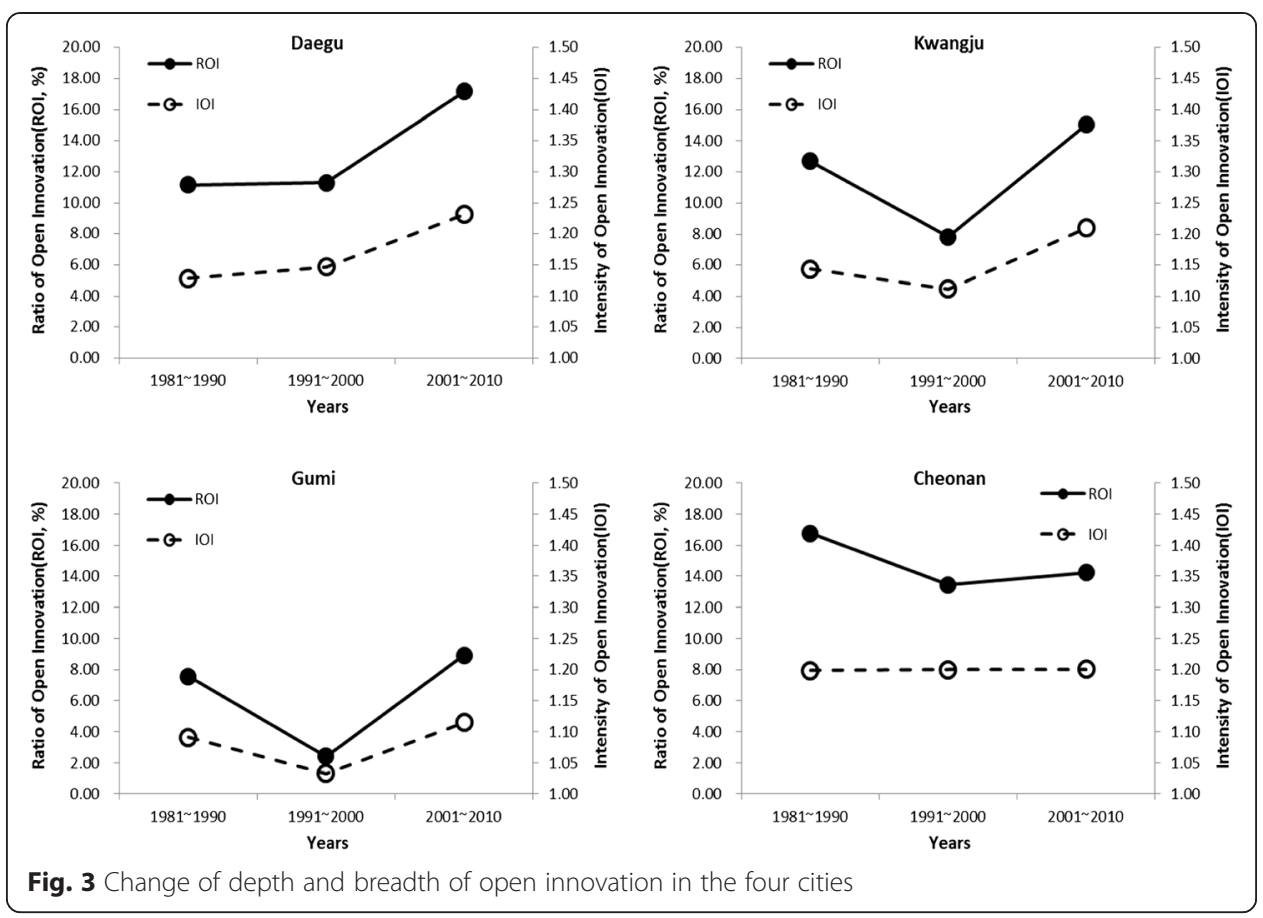

Therefore, this could be interpreted to mean that in the urbanization process, a strategy focusing on the efficiency of a leading company leads to reduction of open innovation of cities. In other words, Hypothesis 1-1, 1-2, and 1-3 were accepted, but Hypothesis 1-4 was rejected. If we assume that patent application activity, or knowledge-asset-production activity, constantly increases during a certain period, and that knowledge-based urbanization also proceeds, the breadth and depth of open innovation will likewise increase. The result is shown in the cases of the four cities. That is, it can be interpreted that knowledge-based urbanization leads to simultaneous increase in the number of cutting-edge patents and to the distribution of knowledge assets, presumably as open innovation patents.

Figure 4 shows Daegu and Kwangju have higher ROI and IOI than Gumi and Cheonan in 2000s, even though their status are a little different in 1980s and 1990s. In particular, large cities (population of a million or more) statistically show that they did not have a high open innovation status, compared with medium and small cities, in the

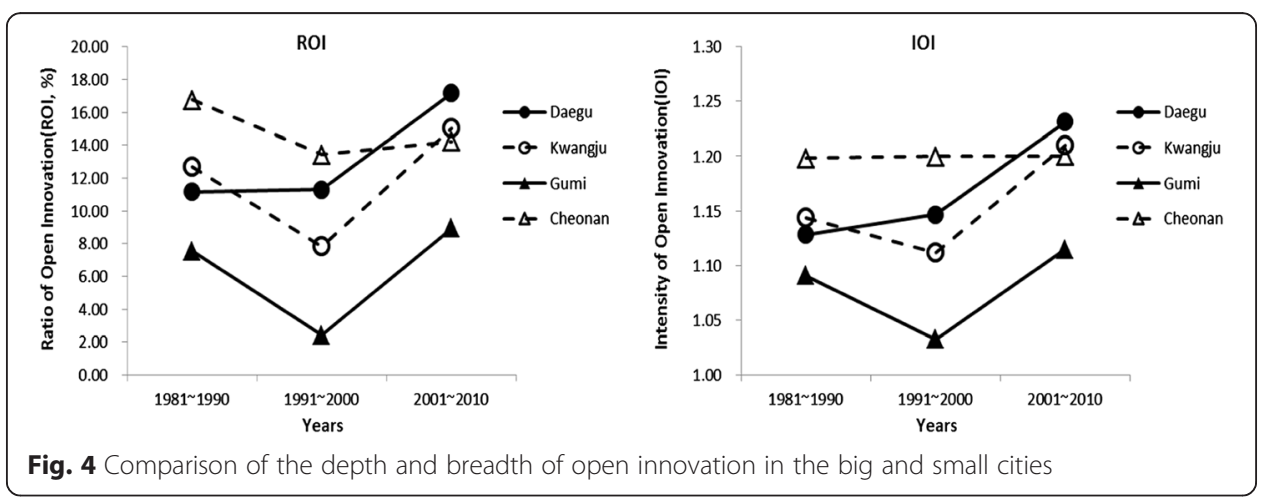


1980s. The total number of the patents of medium and small cities significantly increased in the 2000s, and the breadth and depth of open innovation in large cities was greater than in medium and small cities. In other words, Hypotheses 2-1, 2-2, 2-3, and 2-4 are all accepted. That is, the larger the size of a city, the more its open innovation is activated. The increase in the size of a city leads to an increase in joint patent application cases, and to the increase in the number of joint patent applicants on each patent. Thus, this could be interpreted to mean that the increase in knowledge leads simultaneously to the growth of knowledge-asset production and to the rise in the distribution of knowledge assets.

\section{Change of open innovation in the power law and long tail portions of the patents}

If the top $10 \%$ of all patent applicants were analyzed separately, three cities (except Cheonan) would show higher ROI and IOI in the 2000s than in the 1980s (Fig. 5). All four cities have U-shaped ROI and IOI patterns. However, Cheonan did not have a high ROI and IOI in 2000s. Moreover, it did not reach a higher open innovation status than it had in the 1980s. Thus, Hypotheses 3-1, 3-2, and 3-3 are accepted, but Hypothesis $3-4$ is rejected.

If the lowest $70 \%$ of all patent applicants were analyzed separately, the four cities would have higher ROI and IOI in the 2000s than in the 1980s (Fig. 6). Three of the cities (except Daegu) have a slightly inverse U-shaped ROI and IOI patterns in spite of status differences. However, Daegu shows a slightly U-shaped ROI and IOI patterns. Thus, Hypothesis 4-1, 4-2, 4-3, and 4-4 are all accepted.

The ROI and IOI patterns of the top $10 \%$ and the lowest $70 \%$ of patent applicants exhibit similar patterns in Daegu, but opposite ones in the other three cities. This

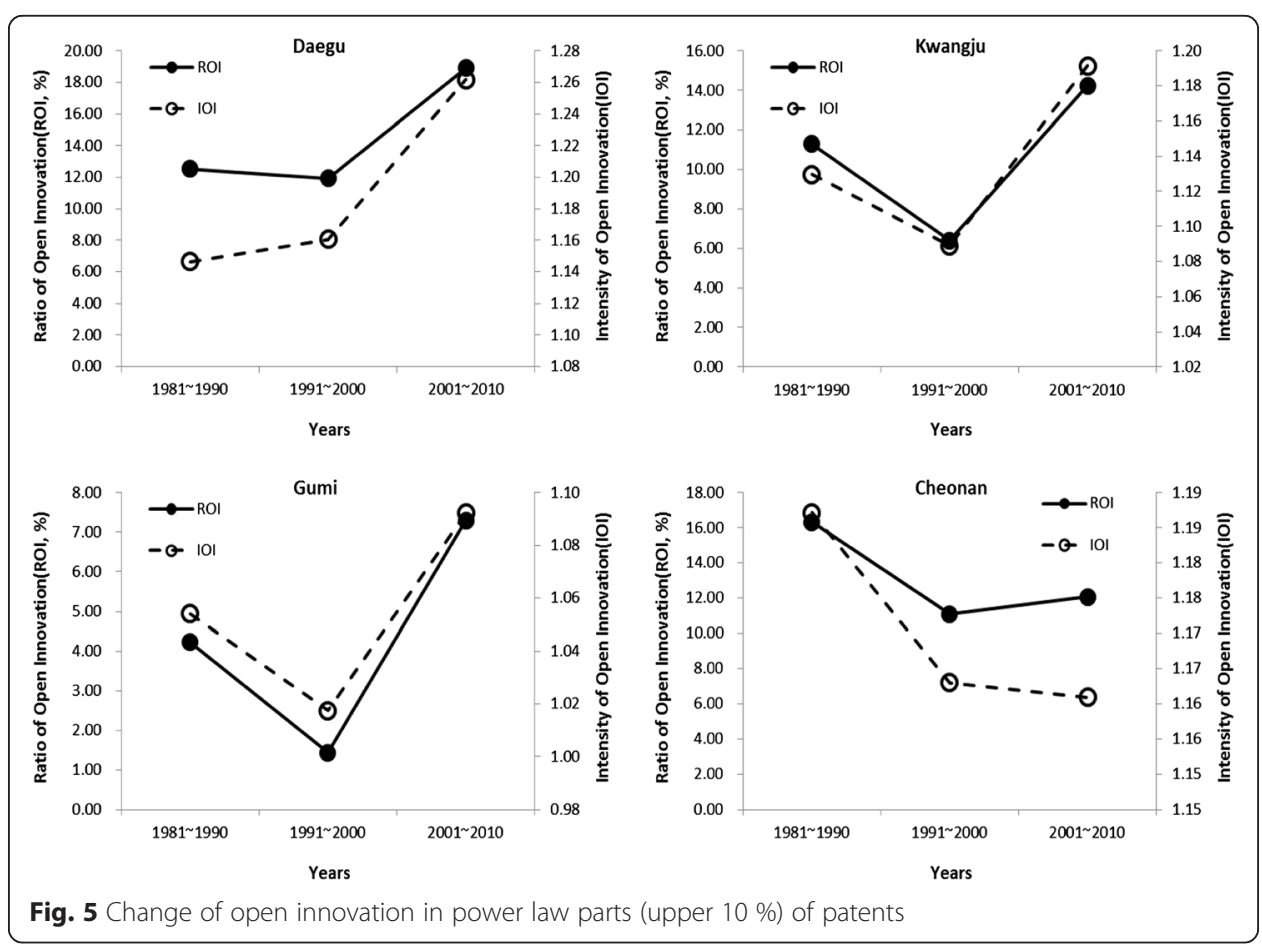




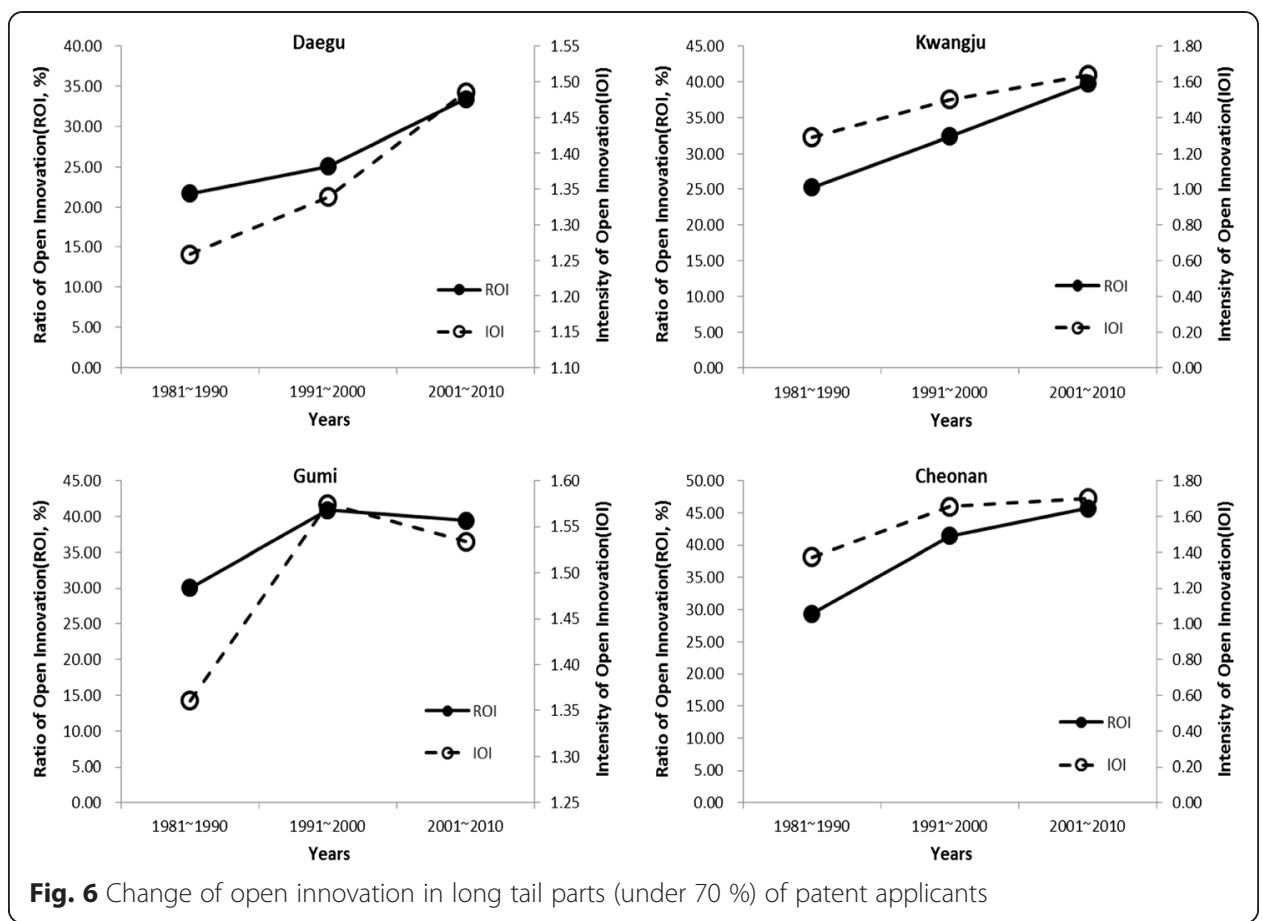

means that in the three cities other than Daegu, large companies that have closed innovation exist along with small- and medium-sized companies (SMEs) that have open innovation. However, Daegu is a city in which business is primarily based upon SMEs. In the other three cities, if the open innovation of the top $10 \%$ of patent applicants is weakened, that of the lowest $70 \%$ is strengthened. However, Daegu does not show opposite patterns. As such, it could be assumed that large companies and SMEs do not coexist.

\section{Discussion: difference of open innovation between power law and long tail parts}

According to the difference in trends between the power law, and the long tail, the ROI and the IOI of the four cities described in Table 3, the total number of patent applications of the top ten percent of applicants continuously increased. However, the ratio was six percent lower in the 2000s compared with that in the 1990s. However, the patent application ratio of the lowest $70 \%$ of applicants increased by eight percent in the 2000s, compared with that in 1990s. The long tail phenomenon of the lowest $70 \%$ in patent application applicants largely occurred

Table 3 Difference in trends between the ratio of the power law to the long tail, ROI, and IOI

\begin{tabular}{|c|c|c|c|c|c|c|c|c|}
\hline \multirow[t]{2}{*}{ Year } & \multicolumn{4}{|l|}{ Top $10 \%$} & \multicolumn{4}{|l|}{ Bottom $70 \%$} \\
\hline & $\begin{array}{l}\text { Ratio in total } \\
\text { patents }\end{array}$ & $\begin{array}{l}\text { Number of } \\
\text { patents }\end{array}$ & $\mathrm{ROI}$ & $\mid \mathrm{IOI}$ & $\begin{array}{l}\text { Ratio in total } \\
\text { patents }\end{array}$ & $\begin{array}{l}\text { Number of } \\
\text { patents }\end{array}$ & $\mathrm{ROI}$ & $\mid \mathrm{IOI}$ \\
\hline $81-90$ & 54.3 & 8091 & 11.69 & 1.14 & 29.2 & 4348 & 23.34 & 1.28 \\
\hline $91-00$ & 75.0 & 34,766 & 7.71 & 1.11 & 16.1 & 7467 & 28.70 & 1.42 \\
\hline $01-10$ & 69.1 & 59,088 & 14.42 & 1.20 & 20.8 & 17,787 & 36.80 & 1.55 \\
\hline Total & 69.5 & 100,586 & 11.97 & 1.16 & 20.1 & 29,134 & 32.94 & 1.48 \\
\hline
\end{tabular}


in industries where customer recommendation or satisfaction had a big impact on the next consumers. This result is identical with that indicated in previous research (Oestreicher-Singer and Sundararajan, 2010). Also, in terms of the patterns of change for ROI and IOI, a clear U-shape was shown for the top $10 \%$ of applicants. However, a slightly inverted U-shape was displayed for the lowest $70 \%$ of applicants. That is, when it comes to the average trend of the four cities, the trend of each city and that of the lowest $70 \%$ of Daegu were a little different. However, in general, they exhibited similar patterns. Moreover, in terms of the total number of patent applications, the lowest $70 \%$ was immensely higher than the top $10 \%$ in ROI and IOI, as shown in Table 3. The ROI and IOI of the lowest $70 \%$ in the four cities were much higher than those of the top $10 \%$ in the other three tenyear intervals as shown in Fig. 5 and Fig. 6.

Above all, in terms of the depth and breadth of open innovation, the lowest $70 \%$ was higher than the top $10 \%$, and the ratio of the patent cases of the lowest $70 \%$ of patent applicants to all patent applications increased, even though this pattern was shown in the 2000s. The two phenomena show that the trend of the increase in patent applications with open innovation of the lowest $70 \%$ of applicants, is changing with that of the rise in the ratio of total patents against the number of all patent applications.

Thus, considering that the lowest $70 \%$ of companies are mainly small- and mediumsized companies or start-ups, the breadth and depth of open innovation in patent applications are needed when a patent is applied for, in order to strengthen intellectual property rights.

In addition, the top $10 \%$ of companies are medium-sized or large companies, as is shown in Appendix 3: Table 6, for the companies among the top 20 patent applicants of the four cities. Thus, if large companies strengthen open innovation during the patent application stage with SMEs, start-ups, or individual researchers, the patent assets of SMEs and start-ups, as well as large companies' patent assets, can increase together.

\section{Conclusion}

Summary

If we summarize the results of this research, they are described in Table 4. As knowledge-based urbanization proceeds, the size of a knowledge city increases, or the lowest $70 \%$ patent applicants rather than the top $10 \%$ apply for patents among patent applicants, and the breadth and depth of open innovation rise. Of course, if the ratio or the impact of a large company is highly influential, other situations may occur. Examples include LG Electronics (Paju, South Korea), Samsung Electronics (in Asan, Tangjeong, and Cheonan, South Korea), Nokia (Oulu, Finland), and automobile companies based in Detroit in the U.S. Cities like these need special effort to strengthen open innovation based on SMEs or start-ups.

\section{Implications}

Knowledge-based urbanization of a city indicates the increase in its open innovation activities, but this first requires the existence of a variety of resources (e.g., colleagues and 
Table 4 Summary of research results and meanings

\begin{tabular}{|c|c|c|}
\hline Hypothesis & Accept or reject & Implication \\
\hline $1-1$ & Accepted & \multirow{4}{*}{$\begin{array}{l}\text { As knowledge-based urbanization proceeds, open innovation also increases } \\
\text { However, if cities dominated by large companies exist, other results may be } \\
\text { produced. }\end{array}$} \\
\hline $1-2$ & Accepted & \\
\hline $1-3$ & Accepted & \\
\hline $1-4$ & Rejected & \\
\hline $2-1$ & Accepted & \multirow{4}{*}{$\begin{array}{l}\text { In the case of a knowledge city, as the size of a city increases, the breadth } \\
\text { and depth of open innovation across the city rise. }\end{array}$} \\
\hline $2-2$ & Accepted & \\
\hline $2-3$ & Accepted & \\
\hline $2-4$ & Accepted & \\
\hline $3-1$ & Accepted & \multirow{4}{*}{$\begin{array}{l}\text { The top } 10 \% \text { of patent applications of a city strengthen the breadth and } \\
\text { depth of open innovation as knowledge-based urbanization proceeds. } \\
\text { However, in cases of cities dominated by large companies or surrounding } \\
\text { cities, exceptional cases may occur. }\end{array}$} \\
\hline $3-2$ & Accepted & \\
\hline $3-3$ & Accepted & \\
\hline $3-4$ & Rejected & \\
\hline $4-1$ & Accepted & \multirow{4}{*}{$\begin{array}{l}\text { The lowest } 70 \% \text { of patent applications of a city strengthen the breadth } \\
\text { and depth of open innovation as knowledge-based urbanization proceeds. } \\
\text { In addition, compared with the top } 10 \% \text {, they promote a much higher } \\
\text { level of open innovation. }\end{array}$} \\
\hline $4-2$ & Accepted & \\
\hline $4-3$ & Accepted & \\
\hline $4-4$ & Accepted & \\
\hline
\end{tabular}

national research institutes) to improve the open-innovation activities of a region or a city. For example, as shown in Appendix 3: Table 6, the top 20 patent applicants in the four cities were closely related to regional establishment and capacity building of colleges or national research institutes with the capability of applying for patents. In addition, strategic approaches need to be adopted by companies and governments (local or national) to improve open innovation among these organizations, SMEs, or start-ups.

Second, to maximize the characteristics of a knowledge city in a large city, the improvement of open innovation across the city is essential. This means that enhancing diverse open innovation in a large city is a core strategy for continuous growth and qualitative development of the city in terms of content.

Third, if strengthening open innovation by SMEs or start-ups is set as a corporate strategy or a government policy, it will become a source of the development of knowledge-based urbanization, and continued economic development of a knowledge city, as well as of the total knowledge assets. In addition, the improvement of open innovation of SMEs and start-ups, along with large companies, will have a positive impact on all of them.

\section{Research limits and additional research topics}

First, this research is limited to the four selected cities in Korea. Further research is needed on global open innovation regions or cities like Silicon Valley in the U.S., and the Zhongguancun High-tech Zone in China.

Second, for this research, 30 years of changes (1981 to 2010) within four cities were analyzed. The study interval should be made larger and future research conducted by applying the framework analysis used in this research. This would provide more universal results and implications extending beyond the special situations inherent in the current study interval. 
Third, this research is limited to mutual patent applications as a target of open innovation. In the future, additional research will need to be conducted on various other open-innovation channels such as patent citations, intellectual property right transfers, licensing, and M\&A. Finally, a great deal more results need to be generated and a wider set of implications need to be drawn.

\section{Appendix 1 Location and basic statistics of the four South Korean cities studied}

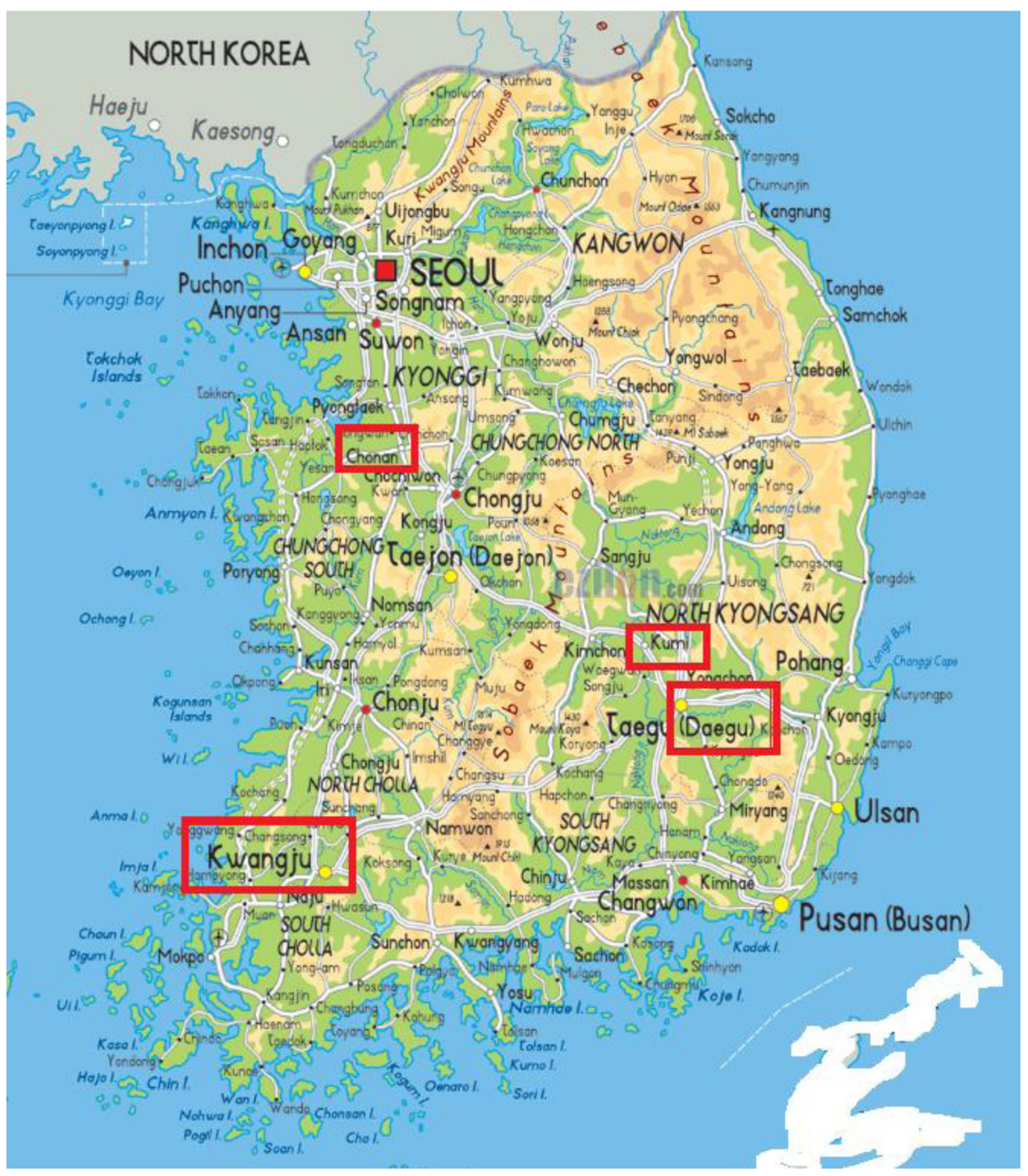

\begin{tabular}{lll}
\hline City & Population (2014) & Gross Regional Domestic Product (GRDP) \\
& & Million dollars (KRW 1000 = USD 1) \\
\hline Daegu & $2,472,000$ & 38,580 \\
Kwangju & $1,489,000$ & 26,401 \\
Gumi (Gumi) & 405,000 & 25,233 \\
Cheonan (Cheonan) & 575,000 & 18,000 \\
\hline
\end{tabular}

Sources: Google Map, (http://www.ezilon.com/maps/images/asia/South-Korea-physicalmap.gif), Korean Statistical Information Service (http://kosis.kr/) 


\section{Appendix 2}

Table 5 WIPO Technology Concordance Table (31 fields) and McKinsey Industry Classification

\begin{tabular}{|c|c|c|c|c|c|}
\hline Category & Section & Subsection & Class & Description & $\begin{array}{l}\text { Mckinsey } \\
\text { Industry } \\
\text { Classification }\end{array}$ \\
\hline 1 & $\begin{array}{l}\text { A (Human } \\
\text { necessities) }\end{array}$ & Agriculture & $\begin{array}{l}\text { A01 (Except } \\
\text { A01N) }\end{array}$ & $\begin{array}{l}\text { Agriculture, forestry, } \\
\text { horticulture, animal } \\
\text { husbandry, etc. }\end{array}$ & 3 \\
\hline 2 & & Foodstuff & $\mathrm{A} 21-\mathrm{A} 24$ & $\begin{array}{l}\text { Baking, dairy products, } \\
\text { fodder, manufacture } \\
\text { of tobacco for } \\
\text { smoking, etc. }\end{array}$ & 3 \\
\hline 3 & & $\begin{array}{l}\text { Personal or domestic } \\
\text { articles }\end{array}$ & $\mathrm{A} 41$ - A47 & $\begin{array}{l}\text { Apparel, footwear, } \\
\text { household equipment, } \\
\text { etc. }\end{array}$ & 2 \\
\hline 4 & & Health/amusement & $\begin{array}{l}\text { A61 - A63 } \\
\text { (Except A61K) }\end{array}$ & $\begin{array}{l}\text { Diagnosis, hospital } \\
\text { supplies, surgical } \\
\text { equipment, toys, } \\
\text { sports, etc. }\end{array}$ & 1 \\
\hline 5 & & Medical & $\begin{array}{l}\text { A61K } \\
\text { (Subclass) }\end{array}$ & $\begin{array}{l}\text { Preparations for } \\
\text { medical, dental, } \\
\text { or toilet purposes }\end{array}$ & 2 \\
\hline 6 & B (Transportation) & Separating/mixing & B01 -B09 & $\begin{array}{l}\text { Separation of } \\
\text { contaminated soil, } \\
\text { physical or chemical } \\
\text { apparatus, nozzle, etc. }\end{array}$ & 3 \\
\hline 7 & & Shaping & B21 - B23 & $\begin{array}{l}\text { Rolling of metal, } \\
\text { processing of wire, } \\
\text { casting, mold, } \\
\text { milling, etc. }\end{array}$ & 2 \\
\hline 8 & & Non-shaping & $\begin{array}{l}\text { B24 - B32 } \\
\text { (Except B31) }\end{array}$ & $\begin{array}{l}\text { Grinding, hand-cutting } \\
\text { tools, plastics, woods, } \\
\text { presses, layered } \\
\text { products, etc. }\end{array}$ & 2 \\
\hline 9 & & Printing & B41 - B44 & $\begin{array}{l}\text { Printer, printing, book, } \\
\text { bureau accessories, etc. }\end{array}$ & 2 \\
\hline 10 & & $\begin{array}{l}\text { Transporting/ } \\
\text { packing }\end{array}$ & $\begin{array}{l}\mathrm{B} 60-\mathrm{B} 64 \\
\mathrm{~B} 65-\mathrm{B} 68\end{array}$ & $\begin{array}{l}\text { Automobile, railways, } \\
\text { cycle, ships, aircraft, } \\
\text { packing, elevator, etc. }\end{array}$ & 2 \\
\hline 11 & & $\begin{array}{l}\text { Microstructural } \\
\text { technology }\end{array}$ & B81 - B82 & $\begin{array}{l}\text { Microtechnology, } \\
\text { nanotechnology, etc. }\end{array}$ & 1 \\
\hline 12 & C (Chemistry) & Chemistry & C01-C05 & $\begin{array}{l}\text { Nonmetallic elements, } \\
\text { compounds of alkali } \\
\text { metals, treatment of } \\
\text { water, fertilizers, etc. }\end{array}$ & 3 \\
\hline 13 & & Organic chemistry & $\begin{array}{l}\text { C07. A01N } \\
\text { (Subclass) }\end{array}$ & $\begin{array}{l}\text { Organic chemistry, } \\
\text { acyclic compounds, } \\
\text { pesticides, etc. }\end{array}$ & 3 \\
\hline 14 & & $\begin{array}{l}\text { Macromolecular } \\
\text { compounds }\end{array}$ & C08 & $\begin{array}{l}\text { Polysaccharides, } \\
\text { treatment of rubbers, } \\
\text { macromolecular } \\
\text { compounds, etc. }\end{array}$ & 3 \\
\hline 15 & & $\begin{array}{l}\text { Petroleum/fine } \\
\text { chemistry }\end{array}$ & C09-C11 & $\begin{array}{l}\text { Paint, adhesives, } \\
\text { petroleum, gas, } \\
\text { alcohol production, } \\
\text { etc. }\end{array}$ & 3 \\
\hline 16 & & Bio & $\mathrm{C} 12-\mathrm{C} 14$ & $\begin{array}{l}\text { Enzymology, microbiology, } \\
\text { fermentation, production } \\
\text { of sucrose, leather, etc. }\end{array}$ & 1 \\
\hline
\end{tabular}


Table 5 WIPO Technology Concordance Table (31 fields) and McKinsey Industry Classification (Continued)

\begin{tabular}{|c|c|c|c|c|c|}
\hline 17 & & Metallurgy & $\begin{array}{l}\text { C21 - C23, } \\
C 25, C 30\end{array}$ & $\begin{array}{l}\text { Manufacture of iron, } \\
\text { coating metallic } \\
\text { material, etc. }\end{array}$ & 2 \\
\hline 18 & D (Textiles) & Textiles & D01 - D07 & $\begin{array}{l}\text { Artificial threads, yarns, } \\
\text { weaving, braiding, } \\
\text { sewing, treatment of } \\
\text { textiles, washing } \\
\text { machine, dryer, dyeing } \\
\text { textiles, etc. }\end{array}$ & 5 \\
\hline 19 & & Paper & $\mathrm{D} 21, \mathrm{~B} 31$ & $\begin{array}{l}\text { Paper-making, pulp } \\
\text { compositions, bags, etc. }\end{array}$ & 4 \\
\hline 20 & $\begin{array}{l}\text { E (Fixed } \\
\text { constructions) }\end{array}$ & Building & E01 - E06 & $\begin{array}{l}\text { Roads, bridges, water } \\
\text { supply, sewerage, } \\
\text { building structure, etc. }\end{array}$ & 5 \\
\hline 21 & & Mining & E21 & $\begin{array}{l}\text { Earth drilling, mining, } \\
\text { quarrying, etc. }\end{array}$ & 5 \\
\hline 22 & $\begin{array}{l}\text { F (Mechanical } \\
\text { engineering) }\end{array}$ & Engines or pumps & F01 - F04 & $\begin{array}{l}\text { Turbine, combustion } \\
\text { engines, pumps, etc. }\end{array}$ & 2 \\
\hline 23 & & $\begin{array}{l}\text { Engineering in } \\
\text { general }\end{array}$ & F15, F16, F17 & $\begin{array}{l}\text { Brakes, clutches, valves, } \\
\text { pipes, lubricating, etc. }\end{array}$ & 2 \\
\hline 24 & & Lighting/heating & $F 21-F 28$ & $\begin{array}{l}\text { Lighting, boilers, } \\
\text { refrigerators, air } \\
\text { conditioners, etc. }\end{array}$ & 2 \\
\hline 25 & & Weapons/blasting & F41, F42, C06 & $\begin{array}{l}\text { Weapons, ammunition, } \\
\text { explosives, etc. }\end{array}$ & 4 \\
\hline 26 & G (Physics) & Instruments/optics & G01 - G03 & $\begin{array}{l}\text { Measuring instruments, } \\
\text { optics, photography, } \\
\text { films, etc. }\end{array}$ & 1 \\
\hline 27 & & Computer & G04 - G08 & $\begin{array}{l}\text { Clocks, control devices, } \\
\text { computers, vending } \\
\text { machines, checking } \\
\text { devices, signaling, etc. }\end{array}$ & 1 \\
\hline 28 & & Information media & G09 - G12 & $\begin{array}{l}\text { Displaying, advertising, } \\
\text { musical instruments, } \\
\text { information storage, etc. }\end{array}$ & 1 \\
\hline 29 & & Nucleonics & G21 & $\begin{array}{l}\text { Reactors, radioactive } \\
\text { sources, etc. }\end{array}$ & 4 \\
\hline 30 & H (Electricity) & $\begin{array}{l}\text { Electric elements/ } \\
\text { semiconductors }\end{array}$ & $\begin{array}{l}\mathrm{H} 01, \mathrm{H} 02, \\
\mathrm{H} 05\end{array}$ & $\begin{array}{l}\text { Cables, electronic parts, } \\
\text { semiconductor devices, } \\
\text { generators, PCBs, etc. }\end{array}$ & 1 \\
\hline 31 & & $\begin{array}{l}\text { Electronics/ } \\
\text { communication }\end{array}$ & $\mathrm{H} 03, \mathrm{H} 04$ & $\begin{array}{l}\text { Amplifiers, wired/wireless } \\
\text { communication, TVs, etc. }\end{array}$ & 1 \\
\hline
\end{tabular}

Notes

1. Highly innovative industries (semiconductors, computers, smart phones, medical devices, etc.)

2. Domestic technology industry (automobiles, electric equipment, medicine, etc.)

3. Manufacturing and processing industry (rubber, plastic, food and beverage, etc.)

4. Energy-intensive industries (paper, mineral extraction, etc.)

5. Labor-intensive industries (spinning and weaving, shoes, etc.) 


\section{Appendix 3}

Table 6 Top 20 patent applicants in four cities

\begin{tabular}{|c|c|c|c|c|c|}
\hline \multicolumn{6}{|l|}{ Daegu } \\
\hline Ranking & Applicant & $1981-1990$ & $1991-2000$ & $2001-2010$ & Total \\
\hline 1 & KDAC & 2 & 2483 & 1107 & 3592 \\
\hline 2 & $\begin{array}{l}\text { Industry-University Cooperation Foundation of } \\
\text { Kyungpook National University }\end{array}$ & 0 & 1 & 1191 & 1192 \\
\hline 3 & Daegu Gyeongbuk Institute of Science \& Technology & 0 & 0 & 415 & 415 \\
\hline 4 & Samsung Commercial Vehicles & 0 & 315 & 0 & 315 \\
\hline 5 & SL Corporation & 42 & 50 & 218 & 310 \\
\hline 6 & $\begin{array}{l}\text { Industry-University Cooperation Foundation of } \\
\text { Keimyung University }\end{array}$ & 0 & 41 & 212 & 253 \\
\hline 7 & Choi Myeong-Bu & 6 & 23 & 163 & 192 \\
\hline 8 & THN Corporation & 3 & 2 & 177 & 182 \\
\hline 9 & Laird Technologies & 0 & 0 & 182 & 182 \\
\hline 10 & Daedong & 24 & 40 & 116 & 180 \\
\hline 11 & Asia Agricultural Machinery & 63 & 88 & 24 & 175 \\
\hline 12 & $J V M$ & 0 & 20 & 150 & 170 \\
\hline 13 & Hyundai Metal & 13 & 132 & 23 & 168 \\
\hline 14 & Namsun Aluminum & 52 & 68 & 44 & 164 \\
\hline 15 & Shelline & 0 & 0 & 150 & 150 \\
\hline 16 & Choi Ki-Young & 60 & 47 & 41 & 148 \\
\hline 17 & Pyeong Hwa Automotive & 0 & 11 & 137 & 148 \\
\hline 18 & Valeo Pyeong Hwa & 3 & 28 & 105 & 136 \\
\hline 19 & $\begin{array}{l}\text { Industry-University Cooperation Foundation of } \\
\text { Yeungnam University }\end{array}$ & 0 & 10 & 124 & 134 \\
\hline 20 & NUC & 0 & 11 & 121 & 132 \\
\hline \multicolumn{6}{|l|}{ Kwangju } \\
\hline 1 & Samsung Gwangju Electronics & 25 & 2815 & 1158 & 3998 \\
\hline 2 & Asia Motors & 77 & 1970 & 0 & 2047 \\
\hline 3 & Kumho Tire & 0 & 8 & 1875 & 1883 \\
\hline 4 & Amkor Technology & 0 & 842 & 501 & 1343 \\
\hline 5 & Gwangju Institute of Science and Technology & 0 & 190 & 1113 & 1303 \\
\hline 6 & $\begin{array}{l}\text { Industry-University Cooperation Foundation of } \\
\text { Chonnam National University }\end{array}$ & 0 & 2 & 989 & 991 \\
\hline 7 & $\begin{array}{l}\text { Industry-University Cooperation Foundation of } \\
\text { Chosun University }\end{array}$ & 0 & 20 & 500 & 520 \\
\hline 8 & Korea Photonics Technology Institute & 0 & 0 & 315 & 315 \\
\hline 9 & Yeon-Sil You & 0 & 20 & 210 & 230 \\
\hline 10 & Yoon-Sun Ok & 0 & 43 & 150 & 193 \\
\hline 11 & Gwan-Sun Cheong & 25 & 53 & 75 & 153 \\
\hline 12 & Jae-Seong Choi & 0 & 26 & 119 & 145 \\
\hline 13 & Carrier & 9 & 37 & 75 & 121 \\
\hline 14 & Hwacheon Technology & 1 & 60 & 56 & 117 \\
\hline 15 & Kyeong-Hee Park & 0 & 13 & 99 & 112 \\
\hline 16 & Dae-Woong Gwon & 0 & 1 & 111 & 112 \\
\hline 17 & Dongseo Electronics & 0 & 0 & 105 & 105 \\
\hline 18 & Kumho E\&C & 6 & 95 & 1 & 102 \\
\hline
\end{tabular}


Table 6 Top 20 patent applicants in four cities (Continued)

\begin{tabular}{|c|c|c|c|c|c|}
\hline 19 & Celrun & 0 & 3 & 71 & 74 \\
\hline 20 & Nam-gu, Gwangju & 0 & 1 & 72 & 73 \\
\hline \multicolumn{6}{|c|}{ Gumi } \\
\hline 1 & Orion Display Solutions & 13 & 6313 & 80 & 6406 \\
\hline 2 & Cheil Industries & 62 & 865 & 2391 & 3318 \\
\hline 3 & Woongjin Chemical & 212 & 794 & 506 & 1512 \\
\hline 4 & Samsung Thales & 0 & 465 & 424 & 889 \\
\hline 5 & Siltron & 0 & 73 & 694 & 767 \\
\hline 6 & LG.Philips Displays & 0 & 0 & 649 & 649 \\
\hline 7 & Top Engineering & 0 & 2 & 492 & 494 \\
\hline 8 & Huen System & 0 & 242 & 147 & 389 \\
\hline 9 & LG Micron & 47 & 180 & 140 & 367 \\
\hline 10 & Toray Saehan & 0 & 58 & 306 & 364 \\
\hline 11 & Samsung Corning Precision Glass & 0 & 2 & 340 & 342 \\
\hline 12 & Toray Advanced Materials & 0 & 0 & 339 & 339 \\
\hline 13 & $\begin{array}{l}\text { Industry-University Cooperation Foundation of } \\
\text { Kumoh National Institute of Technology }\end{array}$ & 1 & 0 & 309 & 310 \\
\hline 14 & LG Siltron & 0 & 0 & 309 & 309 \\
\hline 15 & Samsung Corning Precision Materials & 0 & 0 & 273 & 273 \\
\hline 16 & Goldstar & 123 & 93 & 0 & 216 \\
\hline 17 & Orion PDP & 0 & 42 & 75 & 117 \\
\hline 18 & Epivalley & 0 & 1 & 111 & 112 \\
\hline 19 & Dasan Consultants & 0 & 17 & 94 & 111 \\
\hline 20 & Daewoo Display & 0 & 0 & 105 & 105 \\
\hline \multicolumn{6}{|c|}{ Cheonan } \\
\hline 1 & Semes & 0 & 50 & 2971 & 3021 \\
\hline 2 & Korea Institute of Industrial Technology & 1 & 201 & 1726 & 1928 \\
\hline 3 & Mirae & 4 & 368 & 453 & 825 \\
\hline 4 & Sang-Gwan Han & 7 & 320 & 383 & 710 \\
\hline 5 & Secron & 0 & 15 & 502 & 517 \\
\hline 6 & Coreana & 2 & 93 & 340 & 435 \\
\hline 7 & Novita & 0 & 118 & 241 & 359 \\
\hline 8 & KATECH & 0 & 28 & 209 & 237 \\
\hline 9 & Nifco & 2 & 48 & 129 & 179 \\
\hline 10 & STS Semiconductor \& Telecommunications & 0 & 13 & 140 & 153 \\
\hline 11 & Kyong Dong Engineering & 0 & 13 & 122 & 135 \\
\hline 12 & Bioland & 0 & 8 & 121 & 129 \\
\hline 13 & Advanced Display Materials & 0 & 0 & 122 & 122 \\
\hline 14 & $\begin{array}{l}\text { Industry-University Cooperation Foundation of } \\
\text { Korea University of Technology \& Education }\end{array}$ & 0 & 0 & 116 & 116 \\
\hline 15 & Osstem & 0 & 3 & 95 & 98 \\
\hline 16 & Young-Seok Woo & 16 & 71 & 5 & 92 \\
\hline 17 & Chalkboard & 19 & 55 & 18 & 92 \\
\hline 18 & $\begin{array}{l}\text { Industry-University Cooperation Foundation of } \\
\text { Hoseo University }\end{array}$ & 0 & 10 & 80 & 90 \\
\hline 19 & TSE & 0 & 1 & 89 & 90 \\
\hline 20 & Nexcon Technology & 0 & 20 & 68 & 88 \\
\hline
\end{tabular}




\section{Acknowledgments}

This work was supported by the Daegu Gyeongbuk Institute of Science and Technology(DGIST) and the Korea Institute of Science and Technology Information(KISTI) Under the Ministry of Science, ICT \& Future Planning of Korea.

\section{Author details}

${ }^{1}$ Daegu Gyeongbuk Institute of Science and Technology (DGIST), 50-1 Sang-ri, Hyeonpung-myeon, Dalseong-gun, Daegu 711-873, South Korea. ${ }^{2}$ Korea Institute of Science and Technology Information (KISTI), Hoegi-ro, 66 Dongdemun-gu, Seoul 130-741, South Korea.

Received: 31 August 2015 Accepted: 26 October 2015

Published online: 04 November 2015

\section{References}

Atkinson AB, Harrison AJ. Distribution of personal wealth in Britain. CUP Archive; 1978.

Breschi S, Lissoni F, Montobbio F. The geography of knowledge spillovers: conceptual issues and measurement problems. In: Breschi S, Malerba F, editors. Clusters, networks and innovation. Oxford: Oxford University Press; 2005. p. 343-78.

Brynjolfsson E, Hu Y, Simester D. Goodbye Pareto principle, hello long tail: The effect of search costs on the concentration of product sales. Manag Sci. 2011;57(8):1373-86.

Carrillo F. Knowledge-based development as a new economic culture. Journal of Open Innovation: Technology, Market, and Complexity. 2015:1(1). p. 1-15.

Clauset A, Shalizi CR, Newman ME. Power-law distributions in empirical data. SIAM Rev. 2009;51(4):661-703.

Cooke P. Regional knowledge capabilities and open innovation: Regional innovation systems and clusters in the asymmetric knowledge economy. In: Breschi S, Malerba F, editors. Clusters. Networks and Innovation: Oxford University Press, Oxford; 2005. p. 80-109.

Cooke P, Leydesdorff L. Regional development in the knowledge-based economy: The construction of advantage. J Technol Transf. 2006;31(1):5-15.

Dalziel M. A systems-based approach to industry classification. Res Policy. 2007;36(10):1559-74.

Drăgulescu A. Victor M. Exponential and power-law probability distributions of wealth and income in the United Kingdom and the United States. Physica. 2001:299(1): 213-221.

Dvir R. Knowledge city, seen as a collage of human knowledge moments. In: Carrillo FJ, editor. Knowledge Cities: Approaches. Butterworth-Heinemann (Elsevier), Burlington, MA: Experiences and Perspectives; 2006. p. 245-72.

Elberse A. Should you invest in the long tail? Harv Bus Rev. 2008;86(7/8):88-96.

Enders A, Hungenberg H, Denker HP, et al. The long tail of social networking: Revenue models of social networking sites. Eur Manag J. 2008;26(3):199-211.

Feldman M, Braunerhjelm P. The genesis of industrial clusters. In: Feldman M, Braunerhjelm P, editors. Cluster Genesis: Technology-based Industrial Development. Oxford: Oxford University Press; 2006. p. 1-13.

Fleming, L. Breakthroughs and the "long tail" of innovation. MIT Sloan Management Review. 2012;10.

Florida RL. The Rise of the Creative Class: And How It's Transforming Work. Leisure: Community and Everyday Life, Basic Books, New York; 2002.

Florida RL. Cities and the Creative Class. New York: Routledge; 2005.

Foray D, Lundvall B. The knowledge-based economy: from the economics of knowledge to the learning economy. The Economic Impact of Knowledge; 1998. p. 115-121

Glaeser EL, Kallal HD, Scheinkman JA, Shleifer A. Growth in cities, National Bureau of Economic Research Working Paper Series, No. 3787; 1991.

Han J. Cho O. Platform business Eco-model evolution: case study on KakaoTalk in Korea. Journal of Open Innovation: Technology, Market, and Complexity. 2015:1(1): p. 1-14.

Inkinen T. Reflections on the innovative city: examining three innovative locations in a knowledge bases framework. Journal of Open Innovation: Technology, Market, and Complexity. 2015: 1(1): P. 1-23.

Jaffe AB, Trajtenberg M, Henderson R. Geographic localization of knowledge spillovers as evidenced by patent citations. The Quarterly Journal of Economics. 1993:108(3):577-598.

Kodama F. Shibata T. Demand articulation in the open-innovation paradigm. Journal of Open Innovation: Technology, Market, and Complexity. 2015:1(1): p. 1-21.

Laursen K, Salter A. Open for innovation: the role of openness in explaining innovation performance among UK manufacturing firms. Strateg Manag J. 2006;27(2):131-50.

Levy M, Solomon S. New evidence for the power-law distribution of wealth. Physica A: Statistical Mechanics and its Applications. 1997;242(1):90-4.

Musterd S. Amsterdam as a creative cultural knowledge city: Some conditions. Built Environ. 2004;30(3):225-34.

Nonaka I. A dynamic theory of organizational knowledge creation. Organ Sci. 1994;5(1):14-37.

Oestreicher-Singer G, Sundararajan A. Recommendation networks and the long tail of electronic commerce. Social Science Research Network. 2010. http://dx.doi.org/10.2139/ssrn.1324064 (date accessed).

Patra S.Krishna V. Globalization of R\&D and open innovation: linkages of foreign R\&D centers in India. Journal of Open Innovation: Technology, Market, and Complexity. 2015:, 1(1): p. 1-24

Peterson PE. City Limits. Chicago: University of Chicago Press; 1981.

Raspe O, Van Oort F. The knowledge economy and urban economic growth. Eur Plan Stud. 2006;14(9):1209-34.

Redner S. How popular is your paper? An empirical study of the citation distribution. Eur Physical J B-Condensed Matter and Complex Systems. 1998;4(2):131-4.

Say JB. Cours complet d'économie politique pratique. Bruxelles, Belgium: Société Typographique Belge; 1844.

Siervogel R, Roche AF, Guo S, Mukherjee D. Patterns of change in weight/stature ${ }^{2}$ from 2 to 18 years: findings from long-term serial data for children in the Fels Longitudinal Growth Study. Int J Obes (Lond). 1991;15(7):479-85.

Simester D. When you shouldn't listen to your critics. Harvard Business Review. 2011:89(6): 42-61. 
Yigitcanlar T. Creative Urban Regions: Harnessing Urban Technologies to Support Knowledge City Initiatives: Harnessing Urban Technologies to Support Knowledge City Initiatives. Pennsylvania, USA: IGI Global; 2008.

Yun JJ, Cho BJ. An exploratory study of the economic effect of open innovation. J Science and Technology Policy Manage. 2014;5(1):24-40.

Yun JJ, Park S, Lim D, Hahm D. Emergence of East Asian TFT-LCD clusters: A comparative analysis of the Samsung cluster in South Korea and the Chimei cluster in Taiwan. Asian J Tech Innovation. 2010; 18:(No. 1)201-228.

Yun JJ, Nadhiroh IM, Jung WY. The relationship between open innovation, entrepreneurship, and introduction of new business models in Korean and Indonesian information technology enterprises. Korean Soc Sci J. 2013:40(2):81-99.

Yun JJ, Avvari MV, Jeong E, Lim D. "Introduction of an objective model to measure open innovation and its application to the information technology convergence sector". Int J Tech Policy and Management. 2014;14(4):383-400.

Yun JJ, Won D, Hwang B, Kang J, Kim D. Analysing and simulating the effects of open innovation policies: Application of the results to Cambodia. Science and Public Policy. 2015. doi:10.1093/scipol/scu085.

Submit your manuscript to a SpringerOpen ${ }^{\circ}$ journal and benefit from:

- Convenient online submission

- Rigorous peer review

- Immediate publication on acceptance

- Open access: articles freely available online

High visibility within the field

- Retaining the copyright to your article

Submit your next manuscript at $\boldsymbol{\wedge}$ springeropen.com 